\title{
A RT-PCR ASSAY FOR THE DETECTION OF ENCEPHALOMYOCARDITIS VIRUS INFECTIONS IN PIGS
}

\author{
Lester J. Pérez ${ }^{1}$; Heidy Díaz de Arce ${ }^{1}$ \\ ${ }^{1}$ Grupo de Virología, Centro Nacional de Sanidad Agropecuaria. San José de las Lajas, La Habana, Cuba.
}

Submitted: October 02, 2008; Returned to authors for corrections: November 05, 2008; Approved: May 15, 2009.

\begin{abstract}
Encephalomyocarditis virus (EMCV) infections can cause losses in pig farms all over the world. Rapid, sensitive and unequivocal detection of this virus is therefore essential for the diagnosis and control of the disease. An RT-PCR assay was developed, optimized and evaluated for encephalomyocarditis virus detection in organ based on a pair of primers that amplifies a 165 bp DNA fragment from a highly conserved nucleotide region of the viral 3D glycoprotein. PCR products of the expected size were obtained from Cuban EMCV 744/03 strain. Non-specific reactions were not observed when other porcine RNA genome viruses and uninfected cells were used. The analytical sensitivity of the test was estimated to be $2 \mathrm{TCID}_{50} / 50 \mu \mathrm{L}$. The analysis of tissue homogenate samples from naturally infected animals proved the potential usefulness of the method for a rapid disease diagnosis from field cases.
\end{abstract}

Key words: Encephalomyocarditis virus; RT-PCR assay; pig

\section{INTRODUCTION}

Encephalomyocarditis virus (EMCV) belongs to the genus Cardiovirus classified in the Picornaviridae family (15) that infects many animal species including humans (6, $16,22)$ and has a world-wide distribution (13). Rodents are considered the natural hosts of EMCV, but pigs are the most commonly and severely infected domestic animals (14).

The clinical signs caused by EMCV infections in pigs appear to vary. EMCV can cause myocarditis and encephalitis with high mortality rate in young piglets or reproductive failure in sows (9) leading to important economic losses in pig farms.

The traditional diagnosis of EMCV is based on virus isolation from pig tissues followed by virus identification.
This method is not only time consuming but also it should be considered that the virus is difficult to isolate from pigs after the development of circulating antibody in infected animals $(4,12)$.

The economic losses caused by the disease in world pigs farms and the marked similarity of the clinical picture caused by EMCV and foot-and-mouth disease virus (FMDV), considered as one of the most important animal infectious diseases in very young piglets (14) requires a rapid diagnostic assay to detect unequivocal EMCV infection.

Reverse transcription - polymerase chain reaction (RTPCR) has been proved to be a rapid and sensitive method to detect nucleic acids from related viruses in clinical material $(3,11)$ and some RT-PCR assays have been developed to detect EMCV in clinical samples $(1,20,21)$. However, these

*Corresponding Author. Mailing address: Grupo de Virología, Centro Nacional de Sanidad Agropecuaria. San José de las Lajas, La Habana, Cuba.; Email: lesterjosue@censa.edu.cu 
methods, based on the same primer pair, require two rounds of PCR (20) or the use of magnetic beads to capture the virus via a monoclonal antibody (1) to reach a sensitive EMCV detection.

This paper describes the development, optimization and performance assessment of a simple, rapid and highly sensitive RT-PCR test for detection of EMCV in clinical samples.

\section{MATERIALS AND METHODS}

\section{Viruses and cells}

Baby hamster kidney cell line (BHK21) was maintained in Dulbecco's Minimal Eagle's Medium (DMEM) supplemented with $10 \%$ fetal bovine serum. The EMCV $744 / 03$ strain was originally isolated from a naturally infected pig with typical myocardial form during an outbreak of $\mathrm{EMCV}$ in a pig herd in Cuba and identified following standard procedures (unpublished data). The virus was isolated, passaged and titrated on BHK-21 cells.

The transmissible gastroenteritis virus (TGEV) reference strain Purdue 115, kindly supplied by Pathobiology Laboratory, Gelph University, Canada; the bovine viral diarrhea virus (BVDV) reference strain NADL, and the border disease virus (BDV) reference strain Morendum were both kindly provided by the Community Reference Laboratory (CRL) for CSF, Hannover, Germany; the classical swine fever virus (CSFV) strain Alfort obtained from CISA/INIA, Valdeolmos, Spain were also used in the specificity assays.

\section{Clinical specimens from field samples}

In order to evaluate the efficiency of the extraction method and for the optimization and assessment of the RTPCR assay in clinical samples, a collection of 12 heart and spleen homogenate samples $(10 \% \mathrm{w} / \mathrm{v}$ in PBS) from a 2003 outbreak of clinical disease in Cuba were used. The samples were confirmed, previously, as EMCV positive by isolation and identification following standard procedures (data not shown). Four virus negative heart and spleen samples from uninfected pigs were also included.

\section{Extraction of RNA and cDNA synthesis}

Total RNA was extracted from $250 \mu \mathrm{L}$ amounts of samples (cell cultures, tissue homogenates), with TRI Reagent LS (TRI Reagent LS, SIGMA, San Louis, Missouri, USA) according to the manufacturer's recommendations. RNA was resuspended in $10 \mu \mathrm{L}$ of nuclease free water (Promega, Madison, WI, USA)

First strand complementary DNA (cDNA) was synthesized using Moloney-Murine leukemia virus reverse transcriptase (M-MLV RT) (Promega, Madison, WI, USA) in $20 \mu \mathrm{L}$ final reaction volume. Briefly, $5 \mu \mathrm{L}$ of RNA was incubated with $1 \mu \mathrm{L}$ of random primers $(50 \mathrm{ng} / \mu \mathrm{L})$ (Promega, Madison, WI, USA) and $4 \mu \mathrm{L}$ of nuclease free water (Promega, Madison, WI, USA) in $10 \mu \mathrm{L}$ final reaction volume at $70^{\circ} \mathrm{C}$ for $10 \mathrm{~min}$ and then cooled on ice for the accomplished nucleic acid denaturing to be maintained. After incubation on ice $3.5 \mu \mathrm{L}$ of nuclease free water, $4 \mu \mathrm{L}$ of $5 \mathrm{X}$ reaction buffer $\left[250 \mathrm{mM}\right.$ Tris $-\mathrm{HCl}\left(\mathrm{pH} 8.3\right.$ at $\left.25^{\circ} \mathrm{C}\right), 375 \mathrm{mM}$ $\mathrm{KCl}, 15 \mathrm{mM} \mathrm{MgCl}_{2}, 50 \mathrm{mM}$ DTT], $1 \mu \mathrm{L} 10 \mathrm{mM}$ of each deoxynucleoside triphosphate, $0.5 \mu \mathrm{L}$ of $40 \mathrm{U} / \mu \mathrm{L}$ RNAsin ribonuclease inhibitor and $1 \mu \mathrm{L}$ of $200 \mathrm{U} / \mu \mathrm{L}$ M-MLV RT was added and the reaction mixture was further incubated at $37^{\circ} \mathrm{C}$ for $60 \mathrm{~min}$.

\section{Oligonucleotide primers and restriction endonuclease selection}

EMCV specific primers were designed using the Oligo 6.31 program, (Molecular Biology Insights, Inc., USA) from highly conserved nucleotide region of the viral replicase $\left(3 \mathrm{D}^{\mathrm{pol}}\right.$ ) obtained from the EMCV strain Ruckert (GenBank accession no. M81861). Different EMCV nucleotide sequences available in GenBank (DQ51742; DQ46406; DQ46406; AF356822; X74312.1; X00463.1; AJ235700; AJ235699; Q28885; M81861.1; M54935.1; M38329.1) were previously aligned using Clustal W 1.8 software and manually examined in the search of a highly conserved 
region. A restrictive parameter in the oligonucleotide design was that the primers were not able to amplify different strains of FMDV with nucleotide sequences available in GenBank (EF552693.1, DQ533483.1, AY593751.1)

To prevent false-amplification of other DNAs a BLAST search at National Center for Biotechnology Information (NCBI) site (http://www.ncbi.nlm.nih.gov) was performed using blastn algorithm for calculating sequence similarity with primers selected as query sequences against nucleotide databases of different virus from the Picornaviridae family and random nucleotide sequences.

The forward primer: 5' CCTCTTAATTCGACGCTTGAA-3' (nt 7434 to 7454) and the reverse primer: 5'-GGCAAGCATAGTGATCGAAG-3' (nt 7598 to 7579 ) amplified a 165 base pair (bp) product.

Sequence analysis of the EMCV genome region delimited by EMC-forward/EMC-reverse primers allowed locating an Apa I restriction endonuclease site, splitting the amplicon in two fragments of 104 and $61 \mathrm{bp}$, that was conserved in the EMCV nucleotide sequences analysed. The Apa I restriction endonuclease site was used for additional specificity confirmation of the amplified products.

\section{PCR assay}

A number of experiments were performed to optimize the RT-PCR protocol, including concentration of reagents and PCR cycling parameters. The assay was finally optimized as follows: the reaction mixture was prepared in a volume of $50 \mu \mathrm{L}$ comprised of $2 \mu \mathrm{L}$ of cDNA, 1x GoTaq Green Master Mix (Promega) $\left[200 \mu \mathrm{M}\right.$ of each dNTP, $1.5 \mathrm{mM} \mathrm{MgCl}_{2}(\mathrm{pH}$ 8.5)] and $1 \mu \mathrm{M}$ of each primer. The PCR reaction was carry out under the following conditions in a thermal cycler (Eppendorf Mastercycler): 1 cycle of $2 \mathrm{~min}$ at $95{ }^{\circ} \mathrm{C} ; 35$ cycles of denaturation at $94{ }^{\circ} \mathrm{C}$ for $30 \mathrm{~s}$, annealing at $53{ }^{\circ} \mathrm{C}$ for $30 \mathrm{~s}$, and elongation at $72^{\circ} \mathrm{C}$ for $30 \mathrm{~s}$; and one final cycle of 5 min at $72{ }^{\circ} \mathrm{C}$. The PCR products were visualized by electrophoresis on $2.0 \%$ agarose gel in TBE $0.5 \mathrm{X}$ buffer (90mM Tris-borate, 2 mM EDTA) ethidium bromide stained.
As minimum, one negative tissue homogenate for each batch of RNA extracted samples and one water tube for each amplification assay were included as extraction and amplification negative controls respectively.

\section{Detection limit}

In order to determine the analytical sensitivity of the assay, RT-PCR experiments were performed on ten-fold dilution series of a viral suspension with 105 TCID $50 / \mathrm{mL}$ of Cuban EMCV strain in negative tissue sample from an uninfected donor pig. Purified viral RNAs were obtained as previously described. The RT-PCR detection limit (expressed as TCID50/reaction) was calculated taking into account the volume of sample $(0.25 \mathrm{~mL})$, the fraction of RNA used to synthesize cDNA $(50 \%)$ and the fraction of cDNA used as template in PCR assay (10\%).

\section{Restriction enzyme analysis}

Analysis with Apa I (Promega, Madison, WI, USA) restriction endonuclease of EMCV amplicons was performed in a $20 \mu \mathrm{L}$ volume reaction, using $5 \mu \mathrm{L}$ of the amplification products, previously purified by Wizard $\AA$ PCR Preps DNA Purification System (Promega), and $5 \mathrm{U}$ of enzyme. Reactions were incubated for at least $4 \mathrm{~h}$ at $25^{\circ} \mathrm{C}$. Restriction fragments were analysed by electrophoresis on a $2 \%$ agarose gel ethidium bromide stained.

\section{RESULTS}

A PCR product from the expected size of $165 \mathrm{bp}$ was obtained when RNA from the Cuban EMCV 744/03 strain was used as template. All the 12 tissue field samples from pigs diagnosed as EMCV infected based on clinical signs and laboratory methods yielded the corresponding EMCV amplified product. Specificity of all the EMCV amplicons was furthermore confirmed by Apa I restriction endonuclease analysis which generated the two expected fragments of 104 and $61 \mathrm{bp}$ length. A representative result showing the EMCV 
$744 / 03$ strain endonuclease restriction pattern is shown in Figure 1.

Moreover, the viral genomes of other RNA porcine viruses as follow: TGEV, BVDV, BDV and CSFV were assayed giving not amplification signal (data not shown). Finally, RNA extracted from tissue homogenates samples derived from four virus uninfected pigs, and from an uninfected BHK-21 cell line were also tested showing no positive products in all the cases (data not shown).

The test was proved to be sensitive. The lowest detection limit of the RT-PCR assay was consistently observed to be 2 $\mathrm{TCID}_{50}$ per reaction volume Figure 2.

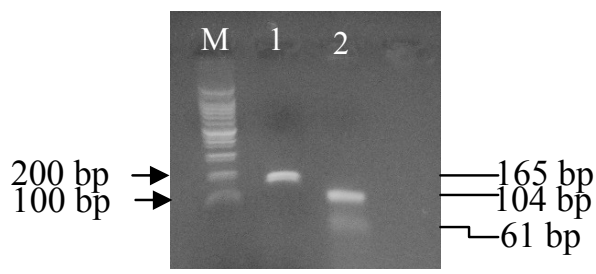

Figure 1. Apa I restriction endonuclease analysis of amplification products of EMCV 744/03 strain. M: molecular weight marker 100 bp (Promega). Lane 1 EMCV amplification products, Lane 2 amplification products after digestion with Apa I.

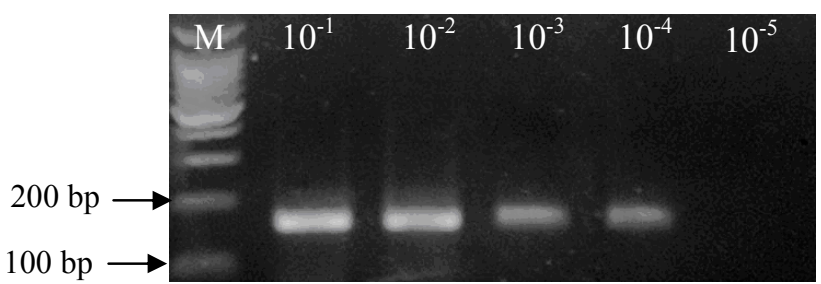

Figure 2. Sensitivity of PCR assay for EMCV detection. RNA's extracted from serial dilutions, in pig tissue homogenate samples, of the EMCV strain viral suspension with a titer of $10^{5} \mathrm{TCID}_{50} / \mathrm{mL}$ were employed under reaction conditions above described. M: molecular weight marker 100 bp (Promega).

\section{DISCUSSION}

In field's conditions EMCV infections must be considered in the differential diagnosis of reproductive disorders in sows (22) and FMDV infections in young pigs (19). In addition, EMCV detection is particularly important in pigs considered to be potential donors for human xenografts which are strongly suggested as a real risk by the experimental infection of mice by transplanting pig tissues infected with EMCV (5).

Moreover, there is concern about the potential of EMCV to become the etiological agent of an emerging disease in the future (9) based on the virus capacity to cross the species barrier reported for rat to pig $(5,17)$, the wide distribution of the virus among vertebrate species, the EMCV strains variation in pathogenicity and tissue tropism (18), and the evolution of $\operatorname{EMCV}(7,10)$.

The PCR assays due to the fact that they are specific, sensitive, can be performed rapidly, and at a moderate cost have proven to be invaluable tools in the diagnosis of viral diseases in veterinary medicine (2). A few RT-PCR assays have been described to detect EMCV in pigs clinical samples $(1,20,21)$ however these methods have some limitations concerning sensitivity.

The RT-PCR assay developed in this study was designed to amplify a $165 \mathrm{bp}$ fragment from the EMCV RNA polymerase (3D) gene (8). This region was highly conserved as shown by aligning of EMCV nucleotide sequences but divergent for FMDV. Also, the BLAST search against nucleotide databases of different picornavirus and random nucleotide sequences revealed that region is very specific for EMCV genomes.

The assay specificity was demonstrated by the absence of amplifications in all heterologous porcine RNA virus evaluated, uninfected BHK-21 cell line and the tissue samples derived from four uninfected pigs.

The assay proved to be very sensitive due to as little as 2 TCID50/50 $\mu \mathrm{L}$ was detected. In particular, the ability to detect $\mathrm{EMCV}$ in all the 12 pig tissue field samples, from 
EMCV natural infected pigs evaluated confirms the sensitivity of the assay. The analysis directly from clinical samples from naturally infected animals proved the potential usefulness of the method for a rapid disease diagnosis from field cases.

This study describes a simple, rapid, sensitive, specific, and cost-effective RT-PCR method for EMCV detection in clinical samples. However, a more careful assessment using field samples is necessary to validate fully this technique for use in routine diagnosis.

\section{REFERENCES}

1. Bakkali-Kassimi, L.; Gonzague, M.; Boutrouille, A.; Cruciere, C. (2002). Detection of Encephalomyocarditis virus in clinical samples by immunomagnetic separation and one-step RT-PCR. J. Virol. Methods. 101, 197-206.

2. Belák, S. (2007). Molecular diagnosis of viral diseases, present trends and future aspects A view from the OIE Collaborating Centre for the Application of Polymerase Chain Reaction Methods for Diagnosis of Viral Diseases in Veterinary Medicine. Vaccine. 25(30), 5444-5452.

3. Belák, S. (2005). The molecular diagnosis of porcine viral diseases: a review. Acta Vet Hung. 53(1), 113-124.

4. Billinis, C.; Paschaleri-Papadopoulou, E.; Anastasiadis, G.; Psychas, V.; Vlemmas, J.; Leontides, S.; Koumbati, M.; Kyriakis, S.C.; Papadopoulos, O. (1999). A comparative study of the pathogenic properties and transmissibility of a Greek and a Belgian encephalomyocarditis virus (EMCV) for piglets. Vet. Microbiol. 70, 179-192.

5. Brewer, L.; Brown, C.; Murtaugh, M.P.; Njenga, M.K. (2003). Transmission of porcine encephalomyocarditis virus (EMCV) to mice by transplanting EMCV-infected pig tissues. Xenotransplantation. 10, $569-576$.

6. Chiu, C.Y.; Greninger, A.L.; Kanada, K.; Kwok, T.; Fischer, K.F.; Runckel, C.; Louie, J.K.; Glaser, C.A.; Yagi, S.; Schnurr, D.P.; Haggerty, T.D.; Parsonnet, J.; Ganem,D.; DeRisi, J.L. (2008). Identification of cardioviruses related to Theiler's murine encephalomyelitis virus in human infections. PNAS. 105(37), 1412414129

7. Christianson, W.T.; Kim, H.S.; Yoon, I.J.; Joo, H.S. (1992). Transplacental infection of porcine fetuses following experimental challenge inoculation with encephalomyocarditis virus. Am. J. Vet. Res. $53,44-47$.

8. Cui, T.; Porter, A.G. (1995). Localization of binding site for encephalomyocarditis virus RNA polymerase in the 30-noncoding region of the viral RNA. Nucleic Acids Res. 23, 377-382.
9. Denis, P.; Liebig, H.D.; Nowotny, N.; Billinis, C.; Papadopoulos, O.; O’Hara R.S.; Knowles, N.J.; Koenen, F. (2006). Genetic variability of encephalomyocarditis virus (EMCV) isolates. Vet. Microbiol. 113, 112.

10. Denis, P.; Koenen, F. (2003). Molecular analysis of the capsid coding region of a virulent encephalomyocarditis virus isolate after serial cell passages and assessment of its virulence. Arch Virol. 148(5), 903-912.

11. Fernández, J.; Agüero, M.; Romero, L.; Sanchez, C.; Belák, S.; Arias, M.; Sanchez-Vizcaino, J.M. (2008). Rapid and differential diagnosis of foot-and-mouth disease, swine vesicular disease, and vesicular stomatitis by a new multiplex RT-PCR assay. J. Virol. Methods.147 (2), 301-311.

12. Foni, E.; Barigazzi, G.; Sidoli, L.; Marcato, P.S.; Sarli, G.; Della-Salda, L.; Spinaci, M. (1993). Experimental Encephalomyocarditis virus infection in pigs. J. Vet. Med. 40, 347-352.

13. Joo, H.S. (1992). Encephalomyocarditis virus. In: Leman, A.D., Straw, B.E., Mengeling, W.L., Allaire, S., Taylor, D.J. (Eds.), Diseases of Swine, 7th Edition. Wolfe Publishing, London, UK, p. 257-262.

14. Joo, H.S. (1999). Encephalomyocarditis virus. In: Straw, B.E. S., D'Allare . Mengeling, W.L., Allaire, S., Taylor, D.J. (Eds.), Diseases of Swine, 8th ed. Iowa State University Press, Ames, USA, p. 139-144.

15. King, A.M.Q.; Brown, F.; Christian, P.; Hovi, T.; Hyypia, T.; Knowles, N.J.; Lemon, S.M.; Minor, P.D.; Palmenberg, A.C.; Skern, T.; Stanway, G. (2000). Picornaviridae. In: Van Regenmortel, M.H.V.; Fauquet, C.M.; Bishop, D.H.L.; Calisher, C.H.; Carsten, E.B.; Estes, M.K.; Lemon, S.M.; Maniloff, J.; Mayo, M.A.; McGeoch, D.J.; Pringle, C.R.; Wickner, R.B. (Eds.), Virus Taxonomy. Seventh Report of the International Committee for the Taxonomy of Viruses. Academic Press, New York, San Diego, USA, p. 657-673.

16. Kirkland, P.D.; Gleeson, A.B.; Hawkes, R.A.; Naim, H.M.; Broughton. C.R. (1989). Human infection with encephalomyocarditis virus in New South Wales. Med. J. Aust. 151, 176-177.

17. Knowles, N.J.; Dinkinson, N.D.; Wilsden, G.; Carra, E.; Brocchi, E.; De Simone, F. (1998). Molecular analysis of encephalomyocarditis viruses isolated from pigs and rodents in Italy. Virus Res. 57, 53-62.

18. Maurice, H.; Koenen, F.; Brocchi, E.; Nowotny, N.; Cruciere, C.; Billinis, C.; Loukaides, P.; Knowles, N.; Nielen, M. (2005). The occurrence of encephalomyocarditis virus (EMCV) in European pigs from 1990 to 2001. Epidemiol. Infect. 133, 547-557.

19. Sellers, R.F.; Daggupaty, S.M. (1990). The epidemic of foot-andmouth disease in Saskatchewan, Canada, 1951-1952. Can J Vet Res. $54,457-464$.

20. Vanderhallen, H.; Koenen, F. (1998). Identification of Encephalomyocarditis Virus in Clinical Samples by Reverse Transcription-PCR Followed by Genetic Typing Using Sequence Analysis. J Clin Microbiol. 36(12), 3463-3467.

21. Vanderhallen, H.; Koenen, F. (1997). Rapid diagnosis of encephalomyocarditis virus infections in pigs using a reverse transcription-polymerase chain reaction. J. Virol. Methods. 66, 83-89. 
Detection of encephalomyocarditis virus

22. Zimmerman, J.J. (1994). Encephalomyocarditis. In: Beran, G.W., Steele, J.H. (Eds.), CRC Handbook Series in Zoonoses. Section B: Viral, 2nd Edition. CRC Press, Boca Raton, FL, p. 423-436. 